\title{
Research on Cost Control of Fixed Assets' Overhaul
}

\author{
Wang Yiyu \\ School of Economics and Management, North China Electric Power University, No.2 Beinong Road, \\ Changping District, Beijing, China \\ 1978090071@qq.com
}

Keywords: Cost quota, General overhaul, Electric power enterprises

\begin{abstract}
This paper, aimed at the problem of electric power enterprises, will describe the way of making the activity-based cost quota of the fixed assets' general overhaul, propose suggestions to optimize and update the overhaul cost quota and illustrate the advantages of putting it into practice, so that they can be in an invincible position in the increasingly fierce market competition. The specific contents will be presented in the paper one by one.
\end{abstract}

\section{Introduction}

Fixed assets, characterized by various types, high value and long lifespan, are the most important assets of electric power enterprises and play an irreplaceable role in the process of production and operation. To make sure that the equipment works, the general overhaul job is essential. However, it has become a difficulty and key point in corporate management due to its ever-changing situations. In reality, the overhaul of fixed assets mainly faces three difficulties: weak awareness of contract management, backward maintenance technology, and the most important one, a lack of cost quota of the general overhaul. This article mainly discusses the latter one. Moreover, most electric power enterprises generally copy the standard cost quota of other companies, such as material cost quota, labor-hour quota and so on. Obviously, this is not accurate, because different companies have different equipment structure, technical level and environmental circumstances. Electric power enterprises nowadays are faced with fierce competition and challenges, they must update their concepts as soon as possible, improve their competitive awareness, and form their mature and effective management system in the market competition. Therefore, it is imperative for electric power enterprises to set tailor-made cost quota to cope with constantly changing situations, improve corporate management and occupy advantages in the market.

\section{The process of setting an activity-based cost quota of the overhaul}

In order to be in a favorable position in the fierce market competition, electric power enterprises have to set cost quota of the overhaul to reduce costs and improve efficiency. By comparing the actual cost with the normal cost in a certain period, the differences can be revealed, and the achievements and existing problems in production and cost management can be pointed out.

\subsection{Select typically fixed assets as the research object}

Selection of typically fixed assets mainly considers the following two factors. For one thing, the selected fixed assets should have a long running time. The collection and analysis of historical data is the key to the establishment of the normal cost of overhaul, and the historical data of those fixed assets with short running time is not enough for the further analysis.

For another, the selected fixed assets should be representative. It means that they must be used in most substations or lines and have no signs of elimination. Choosing fixed assets that are used rarely will directly affect the subsequent comparative analysis work, and the establishment of cost quotas will also be unpractical.

Managers should find their own company's overhauled fixed assets which satisfy two requirements above, make a list, classify them and compare their overhaul frequency with the same 
fixed assets in other electric power corporations. The quality of selected equipment directly affects whether the cost quota has universality, feasibility and operability.

\subsection{Set a standardized activity pool}

The standardized activity pool should be subdivided in the following order: management unit $\rightarrow$ type of fixed assets $\rightarrow$ type of activities $\rightarrow$ details of activities.

Firstly, the management unit is divided into substation and line, which sets up the framework of overhaul cost quota. Secondly, the fixed asset can be classified as transformer, disconnector, GIS, current transformer, voltage transformer, diverter, coupling capacitor, secondary equipment and overhead line. Thirdly, the type of activities is based on corporation's own overhaul activities in recent years. Fourthly, the details of activities are the foundation of data collection and calculation of overhaul cost. Please see Table 1 for details.

Table 1 Standardized activity pool

\begin{tabular}{|c|c|c|c|}
\hline Management unit & Type of fixed assets & Type of activities & Details of activities \\
\hline \multirow{4}{*}{ 500kV substation } & transformer & $\begin{array}{l}\text { Overhaul of bushing } \\
\text { Overhaul of cooling air system } \\
\text {...... }\end{array}$ & $\begin{array}{l}3 \text { items } \\
2 \text { items } \\
\ldots \ldots\end{array}$ \\
\hline & disconnector & $\begin{array}{l}\text { Overhaul of conductive part } \\
\text { Overhaul of drive part } \\
\ldots \ldots \text {.... }\end{array}$ & $\begin{array}{l}4 \text { items } \\
1 \text { item } \\
\ldots \ldots\end{array}$ \\
\hline & Four devices & $\begin{array}{l}\text { Overhaul of current transformer } \\
\text { Overhaul of voltage transformer } \\
\text { Overhaul of diverter } \\
\text { Overhaul of coupling capacitor }\end{array}$ & $\begin{array}{l}\text { 4 items } \\
2 \text { items } \\
3 \text { items } \\
3 \text { items } \\
\end{array}$ \\
\hline & $\ldots \ldots$ & $\ldots \ldots$ & $\ldots \ldots$ \\
\hline \multirow[t]{2}{*}{$550 \mathrm{kV}$ line } & overhead line & $\begin{array}{l}\text { Overhaul of high resistance } \\
\text { Overhaul of earthing } \\
\text { Overhaul of anti-galloping } \\
\text { Overhaul of guyed V tower }\end{array}$ & $\begin{array}{l}3 \text { items } \\
6 \text { items } \\
3 \text { items } \\
2 \text { items } \\
\end{array}$ \\
\hline & $\ldots \ldots$ & $\ldots \ldots$ & $\ldots \ldots$ \\
\hline
\end{tabular}

\subsection{Collect the overhaul cost data}

Electric power enterprises are required to collect data in reverse order, which means that data collection starts from the last step (details of activities), end up in the first step and finally summarize the total cost of each management unit.

When collecting data, the corporations should standardize the information gathering system, such as table format, unit and so forth, to prevent errors caused by the disordered information.

\subsection{Calculate and establish the overhaul cost quota}

When it comes to cost collection, there generally are two possibilities. One is that the expenses of an activity will be directly recorded as the cost of a specific object if all cash is paid for that object. However, if that overhead is impossible to trace back to one specific fixed asset, the expenses should be allocated to multiple objects by choosing proper cost-allocation bases. For example, it is common that several devices are overhauled at the same time, and those costs should be allocated to the different type of fixed assets reasonably. Similarly, if multiple activities take place simultaneously during one overhaul, relevant expenses, such as direct materials costs, payrolls, rental fees and so on, will be allocated among different objects according to the labor hours.

So far, a preliminary overhaul cost quota has been established.

\subsection{Revise and optimize the overhaul cost quota}

On the one hand, to verify the accuracy of the rudimentary cost quota system, managers are supposed to first use it to deduce the historical overhaul cost, and compare the result with the 
existent cost.

On the other hand, to improve the applicability of the cost initial quota system, the conversion factor of overhaul cost between pilot fixed assets and non-pilot fixed assets should be set.

After revised by the operators and approved by the owners, final overhaul cost quota will be formed. Please check Table 2 for details.

Table 2 Cost quota of detailed activities

\begin{tabular}{|c|c|c|c|c|c|}
\hline \multicolumn{2}{|c|}{$02-001$} & Unit & Price per unit & Consumption & Total \\
\hline \multicolumn{6}{|c|}{ Direct material } \\
\hline \multicolumn{6}{|c|}{ Direct machinery } \\
\hline \multirow{2}{*}{ Direct labor } & regular & hour & & & \\
\hline & non-regular & hour & & & \\
\hline \multicolumn{6}{|c|}{ Manufacturing cost } \\
\hline \multicolumn{2}{|c|}{ Non-manufacturing cost } & & & & \\
\hline
\end{tabular}

\section{Advantages of activity-based coat quota of the overhaul}

The establishment of the activity-based cost quota can guarantee, to some degree, to obtain certain profit according to own strength and the market price level, this will be beneficial to survive and seek the development in the electricity market in following aspects.

\subsection{Building a connection between the finance and activities}

The financial staff is rather familiar with the supervision and assessment of total cost, but lack the understanding of the specific details of cost expenditure. The production workers are proficient in each specific activity, but lack a macro grasp of cost management.

Through the establishment of overhaul cost quota, in-depth study of the cost drivers and careful calculation of the cost consumption, electric power enterprises can accurately master the capital requirements and cost factors of general overhaul projects, and help to build a connection between finance and activities.

\subsection{Understanding the cost drivers of the major activities of electric power enterprises}

Because the establishment of overhaul cost quota is based on activities, it can help managers to understand the cost drivers of each activity, find the way of saving expenses, reduce consumption and occupy advantages in the fierce market.

\section{Suggestions for overhaul cost quota}

After the normal costs are completed, electric power enterprises must keep pace with the times and supervise the overhaul cost effectively, they should prevent all kinds of waste and loss, and take timely measures to improve the quality of the normal costs of fixed assets' overhaul.

\subsection{Continuous optimization}

Overhaul cost quota is not static, managers should establish a dynamic adjustment mechanism of 'practice, correction, and re-practice', according to the operating environment, management level, asset quality, personnel quality and other related factors, and then revise this system regularly, combined with cost quota variance analysis in the actual business situation. Such overhaul cost quota is scientific and has practical significance.

\subsection{Regular auditing}

The company should set up an inspection with auditing department as a leader, and the finance department, production department, marketing department and other major departments as members, to audit the cost quota system and supervise the implementation of it. To be more specific, managers can give an order that expenditure of overhaul must be audited once every six months to 
form an internal audit report.

\subsection{Organizational leadership}

Each department leadership should attach great importance to overhaul cost quota. The staff should be arranged reasonably, the problems existing in the work should be solved timely. Electric power enterprises should gradually realize the transformation of cost management, from general control to detailed control, from result control to process control, from financial department control to joint control. Leaders have to jump out of the limitations of traditional costing method and form a scientific cost management mechanism to improve the electric power enterprise management level.

\section{Conclusion}

Overall, as a typical capital-intensive and asset-intensive enterprise, electric power enterprises must lay emphasis on the cost control of fixed assets, classify and summarize of major overhaul activities, trace back from the last link to the top and complete the formulation of quota cost. As long as corporations can actively absorb advanced management concepts, and combine the objective laws of market economy and modern enterprise system, they will adapt to the constantly changing situations, improve corporate management and occupy advantages in the market.

\section{References}

[1] Shen Lirong, The Study on 350kV substation's simulation and anti-accident exercises system[D], North China Electric Power University (Beijing), March, 2012. (In Chinese)

[2] Zhang Hui, Zhang Shuyuan, Zhang Jingyue, Discussion on Design of 110kV Port Substation[J], Port Engineering Technology, June 2018, Vol55, No3. (In Chinese)

[3] Wang Li, Analysis of $35 \mathrm{kV} 110 \mathrm{kV}$ Transmission Lines' Design[J], High-technology \& Industrialization, December, 2012, (12). (In Chinese) 